\title{
URGENSI PENERAPAN PEMBELAJARAN BERBASIS MINAT SISWA
}

\section{SMP}

\author{
${ }^{(1)}$ Erhansyah \\ erhanalbanjari@gmail.com \\ SMP Negeri 1 Muara Muntai
}

\section{Tersedia Online di \\ http://www.jurnal.unublitar.ac.id/ index.php/briliant}

\section{Sejarah Artikel}

Diterima pada 5 Juli 2018

Disetuji pada 3 November 2018

Dipublikasikan pada 20

November 2018 Hal. 385-391

\section{Kata Kunci:}

Urgensi, Minat dan Pembelajaran

\section{DOI:}

http://dx.doi.org/10.28926/briliant .v3i3.208

\begin{abstract}
Abstrak: Penerapan pembelajaran berbasis minat pada siswa ketika proses kegiatan belajar mengajar akan menambah daya aktivitas siswa. Siswa yang mempunyai minat yang tinggi terhadap sebuah objek khususnya mata pelajaran tentu akan membangkitkan motivasi dan meningkatkan aktivitas dan rasa keingintahuannya terhadap sebuah mata pelajaran. Dan minat tentu saja dimiliki oleh segenap siswa yang terlibat dalam proses pembelajaran. Pemberdayaandan penerapan minat siswa ini sejatinya harus didorong oleh komponen proses pembelajaran yang melingkupinya. Sementara motivasi dan rasa ingin tahu siswa yang tinggi akan meningkatkan pula aktivitas belajarnya terhadap sebuah mata pelajaran. Penerapan pembelajaran berbasis minat siswa ini menjadi urgent ketika ketercapaian proses
\end{abstract} dari kegiatan pembelajaranyang maksimal menjadi tujuan yang diinginkan.

\section{PENDAHULUAN}

Keberhasilan sebuah proses pembelajaran dan tercapainya tujuan dari proses belajar itu sendiri sesungguhnya banyak faktor yang melingkari sekaligus saling mempengaruhi. Siswa sebagai objek dan subjek dari proses ini menjadi komponen yang sangat penting untuk ditelisik keberadaannya baik sumbangan pengaruh yang datang dari dirinya sendiri maupun yang dampak dari kepiawaian pengaruh yang berasal dari luar dirinya untuk keberhasilan dan ketercapaian dari hasil belajarnya.

Minat tentu saja dimiliki oleh segenap siswa yang terlibat dalam proses pembelajaran. Tetapi pemberdayaan minat siswa ini sejatinya harus didorong oleh komponen proses pembelajaran yang melingkupinya. Siswa yang mempunyai minat pas pasan tentu memerlukan dorongan dan pengarahan yang lebih ketimbang siswa yang mempunyai minat yang tinggi terhadap sebuah proses pembelajaran.

Komponen lain yang berperan penting dalam implementasi minat siswa adalah manager kelas yakni guru. Karena meski guru merupakan faktor yang memberikan sumbangan pengaruh dari luar terhadap minat siswa, tetapi keberadaannya sangat dibutuhkan untuk memberikan dorongan dan arahan terhadap siswa terlebih dalam lingkup pendidikan pada level yang rendah.

Hasil belajar sebagai tujuan akhir dari proses pembelajaran adalah menjadi tolak ukur untuk kebermaknaan dari kemampuan siswa dan dorongan serta arahan dari guru dalam mengimplementasikan minat belajar pada diri siswa itu sendiri. 
Dengan demikian penerapan minat pada proses pembelajaran kuhususnya pada level Sekolah Menengah Pertama (SMP) menjadi urgens, karena minat sejatinya menjadi pendorong semangat bagi diri siswa itu sendiri.

\section{PEMBAHASAN \\ Peran Guru}

Proses pembelajaran seyogyanya menginginkan sesuatu yang dicapai. Sesuatu yang ingin dicapai itu disebut dengan tujuan. Dalam perencanaan, pelaksanaannya proses tersebut tentu saja dipengaruhi oleh beberapa macam faktor. Sebagaimana dikemukakan Sumadi Suryabrata bahwa ada beberapa faktor yang mempengaruhi keberhasilan belajar siswa, seperti: (a) faktor-faktor yang berasal dari luar diri siswa yaitu faktor-faktor sosial dan faktor-faktor non sosial, dan (b) faktor-faktor yang berasal dari dalam diri siswa yaitu faktor-faktor fisiologis dan faktor-faktor psikologis (Suyabrata : 1990 : 249). Seorang pengajar atau guru dalam hal ini tentulah faktor yang berada di luar diri siswa, namun demikian dalam proses sesungguhnya ia dapat mempengaruhi proses internal yang ada dalam diri siswa itu sendiri. Guru menjadi faktor yang mempengaruhi hasil belajar siswa karena guru sendiri dalam melaksanakan proses pembelajarannya diperlukan beberapa syarat sebagaimana menurut Ali bahwa syarat yang perlu dimiliki guru antara lain : a) penguasaan materi, b)kemampuan menerapkan prinsip-prinsip psikologis, c) kemampuan menyelenggarakan proses mengajar belajar, dan d) kemampuan menyesuaikan diri dengan berbagai situasi (Ali, 1987: 7).

Dengan kemampuan yang ada pada dirinya tentulah guru memberikan kontribusi dan peran penting serta salah satu faktor yang dapat mempengaruhi proses dan hasil belajar siswanya. Dengan demikian faktor eksternal yakni salah satunya adalah guru memiliki peranan yang cukup penting mempengaruhi hasil belajar adalah tenaga pengajar (guru) sebagaimana menurut Cece Wijaya dan A. Tabrani Rusyan bahwa kegiatan pembelajaran di depansiswa adalah perwujudan interaksi dalam proses komunikasi dan tenaga pengajar sebagai pemegang kunci sangat menentukan terhadap pencapaian hasilan belajar (Wijaya : 1992 : 5). Sedangkan pendapat Nana Syaodih Sukmadinata yang mana pelaksanaan (implementasi) kurikulum hampir seluruhnya bergantung pada kreativitas, kecakapan, keterampilan, kesanggupan dan ketekunan tenaga pengajar (Sukmadinata : 1997 : 200 ). Jadi tegasnya adalah bahwa sebaik-baiknya sebuah kurikulum sebagai kerangka acuan dalam mencapai tujuan tentu sangat tergantung kepada tenaga pengajar atau gurunya.

Di luar faktor eksternal seperti kualitas tenaga pengajar (guru), menurutDalyono bahwa faktor-faktor yang mempengaruhi hasil belajar terdapat juga faktor internal siswa yaitu yang berasal dari dalam diri siswa yaitu (1) kesehatan (2) intelegensi dan bakat (3) minat dan motivasi (4) cara belajar ( Dalyono: 2007 : 55 ).

Ketercapaian dan keberhasilan secara formal legalitas siswa dapat dilihat melalui: (1) hasil belajar selama di lembaga pendidikan dengan buku raport, dan (2) hasil belajar setelah lulus dari lembaga pendidikan dengan diterbitkannya ijazah atau surat keterangan lainnya yang sah menurut undang undang. 
Dengan demikian perpaduan faktor eksternal dan internal yang mempengaruhi dari proses pembelajaran ini sesungguhnya menjadi sumber, sekaligus potensi setiap siswa dalam mencapai keberhasilan yang ingin dicapai.

\section{Hasil Belajar}

Pengertian belajar seperti yang dijelaskan Gagne dan Driscoll adalahperubahan kemampuan dan disposisi dari seseorang yang dapat dipertahankan dalam suatu waktu tertentu dan bukan disebabkan oleh proses pertumbuhan. Macam-macam pertumbuhan yang dimaksud dalam belajar adalah mencakup perubahan tingkah laku setelah seseorang mendapat berbagai pengalaman dalam berbagai situasi belajar. Berdasarkan pengalaman-pengalaman itu akan menyebabkan proses perubahan yang terjadi dalam diri seseorang. (Gagne : 1988 : 4)Selain itu dengan pernyataan yang sama menurut Gagne dalam Suprijonomenyatakan bahwa "belajar adalah perubahan disposisi atau kemampuan yang dicapai seseorang melalui aktivitas" ( Supriyono : $2013: 2$ ). Sependapat dengan itu Gredler mengatakan bahwa belajar merupakan suatu proses seseorang dalam memperoleh berbagai kecakapan, keterampilan dan sikap dan belajar itu tidak datang begitu saja, tetapi harus dilaksanakan dengan sengaja dalam waktu yang tertentu pula ( Gredler : $1986: 2$ ).

Menurut Suyono dan Hariyanto "belajar adalah suatu aktivitas atau suatu proses untuk memperoleh pengetahuan, peningkatan keterampilan, memperbaiki prilaku, sikap, dan mengkokohkan kepribadian" ( Suyono : $2012: 9$ ).

Dari uraian di atas dapat disimpulkan bahwa belajar adalah perubahan kemampuan seseorang dan dapat dipertahankan dalam kurun waktu tertentu. Berbagai pertumbuhan yang terjadi dalam belajar itu, seperti perubahan tingkah laku setelah seseorang siswa mendapat berbagai pengalaman pada berbagai situasi belajar itu sendiri, sehingga dari berbagai pengalaman itu akan menyebabkan proses perubahan yang terjadi dalam diri seseorang siswa.

Sedangkan belajar menurut Sukardi dan Maramis adalah perubahan perilaku siswa secara bertahap, terarah melalui suatu proses terencana dan bertahap, sehingga siswa pada akhir pembelajaran kelak mempunyai kemampuan atau keterampilan sesuai dengan apa yang dituju oleh sistem pembelajaran (Sukardi : 1996) : 91). Kemudian menurut Sujana, belajar adalah suatu proses yang ditandai dengan adanya perubahan pada diri seseorang.Perubahan yang dimaksud adalah hasil dari proses yang ditunjukkan dalam berbagai bentuk berubahan dari aspek: (a) pengetahuan, pemahaman, sikap, minat, dan tingkah laku seseorang, dan (b) keterampilan, kecakapan, kebiasaan, serta pemahaman aspek lain yang terdapat pada seseorang peserta didik dalam belajar yang bersifat relatif menetap (Sujana : $1988: 6$ ).

Proses pembelajaran akan mdnjadikan perubahan perilaku siswa secara bertahap, terarah melalui suatu proses terencana dan bertahap, sehingga siswa pada akhir proses belajarnya mendapatkan kemampuan dan keterampilan sesuai dengan apa yang telah ditargetkan dalam rencana pembelajaran.

Berdasarkan pendapat para ahli di atas, maka belajar pada dasarnya ditandai dengan: (1) perubahan terhadap perilaku, (2) diperolehnya lewat pengalaman, (3) hasilnya relatif menetap, (4) perubahannya berkaitan aspek fisik dan mental. Penyebab perubahan perilaku ini tidak diakibatkan oleh proses pertumbuhan yang sifatnya fisiologis. 
Dengan demikian maka belajar adalah proses perubahan tingkah laku seseorang peserta didik yang berlangsung dalam kurun waktu tertentu, seperti pengetahuan, pemahaman, keterampilan, nilai, sikap dan minat seseorang peserta didik dari pengalaman yang diterimanya dari lingkungan dimana terdapat situasi belajar terjadi.

Menurut Brigg hasil belajar adalah seluruh kecakapan dan hasilnya yang diraih melalui proses pembelajaran di lembaga pendidikan dan ditetapkan dengan angka-angka yang diukur berdasarkan test hasil belajar. (Briggg : 1979 : 150) Sedangkan Sukardli dan Maramis mengatakan bahwa mengukur adalah menerapkan alat ukur terhadap objek tertentu. Besaran-besaran angka yang diperoleh, barulah memperoleh makna apabila dibandingkan hasil pengukuran dengan suatu patokan tertentu. (Sukardi : 1996 : 69) Syamsuddin mengemukakan bahwa perbuatan dan hasil belajar ditentukan dalam bentuk: (a) pertambahan materi pengetahuan yang berupa fakta, (b) penguasaan bentuk psikomotorik, dan (c) Perbekalan dalam kaitannya dengan kepribadian seseorang siswa (Syamsudin: 1990 : 9).

Pengukuran menurut Silvarius adalah suatu proses pemberian angka pada sesuatu atau seseorang berdasarkan aturan tertentu (Silvarius : $1991: 6$ ). Terdapat empat fungsi pengukuran terhadap mahasiswa seperti yang ditetapkan Popham, yaitu:(1) untuk menentukan kelemahan dan kelebihan mahasiswa secara perorangan, (2) untuk meningkatkan hasil belajar mahasiswa yang memuaskan, dan (3) untuk mengumpulkan bukti dalam rangka menetapkan peringkat mahasiswa, dan (4) untuk memprediksi tentang keefektifan pembelajaran yang telah dilaksanakan (James : $1995: 5$ ).

Mengukur berarti menerapkan alat ukur terhadap objek tertentu. Besarnya angka yang didapatnya, barulah dikatakan bermakna jika dibandingkan hasil pengukuran dengan sesuatu patokan tertentu. Hasil belajar menurut Romiszowski dapat ditetapkan dalam tiga kategori, yaitu: kognitif, psikomotorik, dan afektif. Semua aspek tersebut dapat dikatakan sebagai keterampilan menerima informasi dan menyalurkan kepada pihak yang lain (Rowinszowski : 1981 : 250).

Dari pendapat para ahli di atas, maka dapat disimpulkan bahwa hasil belajar adalah sebuah tujuan yang dicapai setelah mengalami pengalaman dalam kegiatan pembelajaran, sehingga prinsip-prinsip dari Taksonomi Bloom sangat bermanfaat dalam merancang berbagai tingkat tujuan pembelajaran. Maka dengan demikian hasil belajar siswa dalam tulisan ini didasarkan pada konsep Taksonomi Bloom tersebut yang mengklasifikan hasil belajar di sekolah berdasarkan konsep taksonami bloom yang meliputi tiga ranah, yaitu: (1) kognitif, adalah yang berhubungan dengan kemampuan berfikir, (2) afektif, adalah yang berkenaan dengan minat, sikap dan perasaan, dan (3) psikomotorik, adalah yang berkaitan dengan kemampuan gerak. (Wingkel : 2004 : 245) Kemudian menurut Davies yang menyatakan bahwa tujuan khusus pendidikan/pembelajaran secara luas dapat dikelompokkan ke dalam salah-satu dari tiga kelompok tujuan seperti berikut ini, yaitu: (1) tujuan kognitif, adalah yang berhubungan dengan informasi dan pengatahuan, karena itu usaha untuk tercapainya tujuan kognitif adalah suatu kegiatan pokok program pendidikan dan pelatuhan, (2) tujuan afektif, adalah yang menekankan pada sikap dan nilai, perasaan san emisi, dan (3) tujuan psikomotorik, adalah yang berhubungan dengan keterampilan motorik, manipulasi benda, atau kegiatan yang memerlukan koordinasi saraf dan anggota badan (Davis 
: $1991: 97)$.

Dari uraian di atas, maka dapat disimpulkan bahwa hasil belajar adalah hasil belajar yang diraih siswa setelah mengalami pengalaman belajar dalam sebuah mata pelajaran yang telah diikutinya.

\section{Urgensi Minat Terhadap Hasil Belajar}

Menurut Syahminat adalah kecenderungan dan kegairahan yang tinggi atau keinginan yang besar terhadap sesuatu (Syah: 2011: 152). Sementara itu Slameto mengatakan bahwa minat adalah suatu rasa lebih suka dan rasa ketertarikan pada suatu hal atau aktivitas, tanpa ada yang menyuruh (Slameto : 2010: 180).

Menurut Djamarah pendidikan yang paling efektif untuk membangkitkan minat belajar pada siswa adalah dengan menggunakan minat- minat siswa yang telah ada dan membentuk minat-minat baru pada diri siswa. Hal ini dapat dicapai dengan jalan memberikan informasi pada siswa mengenai hubungan antara suatu bahan pengajaran yang akan diberikan dengan bahan pengajaran yang lalu, menguraikan kegunaan bagi siswa dimasa yang akan datang. Minat dapat dibangkitkan dengan cara menghubungkan materi pelajaran dengan suatu berita sensasional yang sudah diketahui kebanyakan siswa (Djamarah : 2009 : 158).

Minat menurut pendapat Skinner adalah suatu dorongan yang menunjukkanperhatian seseorang terhadap objek yang menarik, menyenangkan apabila seseorang memperhatikan suatu objek yang menyenangkan, maka akan berupaya dengan aktif untuk meraih objek tersebut (Skinner : 1976 : 335). Dengan demikian, seseorang baru dapat diketahui minatnya, apabila ia berkeinginan atau menyukai sesuatu objek atau minat seseorang dapat dibaca jika ia memperlihatkan rasa suka atau senangnya kepada suatu objek tersebut.

Berkaitan dengan tinggi dan rendahnya minat seseorang terhadap suatu objek tertentu sangat berhubungan dengan yang membutuhkan objek tersebut (Crowl : 1996 : 94). Menurut Ahmadi berkaitan dengan pentingnya minat siswa dalam belajar, karena sesuatu mata pelajaran dapat dipelajari dengan baik apabila ada pemusatan perhatian (niat) terhadap mata pelajaran, dan minat merupakan salah satu faktor yang mungkin terjadinya konsentrasi itu terjadi (Ahmadi : 1991 : 6). Sejalan dengan itu, Hasaini dan Nur mengemukakan bahwa minat adalah perhatian yang mengandung unsur-unsur perasaan seseorang (Hasani : 1986 : 91).

Berdasarkan uraian di atas dapat dikatakan bahwa minat itu bukanlah sesuatu yang dibawa sejak lahir, tetapi lahir dari pengalaman belajar siswa, karena minat merupakan manifestasi dari hasil belajar yang lahir dari siswa akibat interaksi minat yang ada dalam lingkungannya. Pada minat juga dapat mengalami perubahan sesuai dengan perubahan status, tanggung jawab, dan cara hidup seseorang siswa.

Dari Mulyasa menjelaskan bahwa minat adalah kecenderungan seseorang dalam mengerjakan sesuatu perbuatan, seperti minat untuk mempelajari sesuatu dalam hal membaca, menulis, atau berdiskusi (Mulyasa : 2004 : 194). Sedangkan Fajar menjelaskan bahwa situasi pembelajaran berlangsung efektif bila adanya minat dan perhatian siswa dalam belajar. Dengan demikian, maka minat siswa sangat besar pengaruhnya dalam belajar, karena dengan adanya minat siswa akan mengerjakan sesuatu yang diminatinya. Begitu juga sebaliknya bagi siswa yang tidak berminat, maka tidak akan melakukan sesuatu dalam kegiatan belajar. Dengan demikian setiap siswa haruslah mempunyai minat dalam belajar dan 
tenaga pengajar seharusnya berupaya untuk membangkitkan minat siswanya dalam mengikuti kegiatan pembelajaran (Fajar : $2002: 12$ ).

Menurut Mulyasa bahwa kecenderungan dan kegairahan yang tinggi atau keinginan yang besar terhadap sesuatu, yang kemudian dapat mempengaruhi pencapaian hasil belajar dalam mata pelajaran tertentu dan itulah yang dimaksud dengan minat (Mulyasa : 2004 : 194).

Proses pembelajaran sebuah mata pelajaran mempunyai hubungan yang erat dengan kondisi individu atau siwwa sebagai subjek dan objek pendidikan. Ketika siswa merasa senang dan gembira dalam melakoni proses tersebut maka proses belajar akan terkondisi dengan baik. Kegembiraan dan kesenangan siswa tentulah diawali dengan kemauan untuk belajar dan itu semua diawali dengan minat siswa dimaksud. Siswa yang mempunyai minat tentulah membuat proses penerimaan materi pelajaran akan berjalan antusias dan menyenangkan, sehingga pada gilirannnya akan membuat siswa rajin belajar, tercipta dorongan untuk berkarya dan beraktivitas positif dikarenakan terjadinya dorongan yang signifikan dalam dirinya.

\section{KESIMPULAN}

Proses pembelajaran sejatinya juga dapat dilakukan dengan memperhatikan minat siswa terhadap objek tertentu. Karena penerapan pembelajaran berbasis minat pada siswa akan menambah daya aktivitasketika proses kegiatan belajar.Siswa yang mempunyai minat yang tinggi terhadap sebuah objek khususnya mata pelajaran tentu akan membangkitkan motivasi dan meningkatkan rasa keingintahuannya terhadap sebuah mata pelajaran. Motivasi dan rasa ingin tahu siswa yang tinggi akan meningkatkan pula aktivitas belajarnya terhadap sebuah mata pelajaran. Penerapan pembelajaran berbasis minat siswa ini menjadi urgen ketika ketercapaian proses dari kegiatan pembelajaran yang maksimal menjadi tujuan yang diinginkan.

\section{SARAN}

Dari kajian yang telah dipaparkan, maka minat siswa menjadi urgen ketika menginginkan proses pembelajaran. Agar minat siswa dapat dtelisik secara mendalam dan detil maka pendidik tentu saja dapat melakukan sebuah kajian dan penelitian yang mendalam dan detil pula. Sehingga pendidik tentu akan mudah melakukan proses pembelajaran ketika mengetahui secara mendalam dan detil setiap siswa terutama minat yang ada pada dirinya.

\section{DAFTAR RUJUKAN}

Ahmadi, Abu, Teknik Belajar Yang Efektif. Jakarta: Rineka Cipta, 1991.

Brigg, Lislie J., Instructional Design and Applications. Englewood, NJ:

EducationalTechnology Publication, Inc, 1979.

Crowl, Thomas K., Educational Psychology Window in Teaching. New York: Brownand Benchmark, 1996.

Fajar, Ernie, Portofolio Dalam Pelajaran IPS. Bandung: Remaja Rosdakarya, 2002.

Gagne, Robert M. dan Merey Perkins Driscoll, Essential of Leaning for Instruction. Englewood Cliff. N.J: Prentice Hall, 1988.

Gredler, Margareth E. Mell, Leaning and Instruction: Theory Into Practice. New 
York : Maemillan, 1986.

Hasaini dan Nur, Himpunan Istilah Psikologi. Jakarta: Mutiara Sumber Widya, 1986. Mulyasa, E., Kurikulum Berbasis Kompetensi: Konsep

Karakteristik dan Implementasi.Bandung: Remaja Rosda Karya, 2004.

Implementasi Kurikulum 2004: Panduan Pembelajaran KBK. Bandung: RemajaRosda Karya, 2004.

Rooijakkers, Ad., Mengajar dengan Sukses. Jakarta: Gramedia, 1990.

Rowinszowski, Designing Intructional System Decision Making in Course

Planning. New York, Nicholas Publishing, 1981.

Skinner, Charles E., Educational Psychology. Toronto : Prentice Hal, 1976.

Sujana, Nana, Cara Belajar Siswa Aktif dalam Proses Belajar Mengajar.

Bandung :Sinar Baru, 1988.

Sukardi, E. dan W. F. Maramis, Penilaian Keberhasilan Belajar. Surabaya: AirlanggaUniversity Press, 1996.

Suryabrata, Sumadi, Psikologi Pendidikan. Jakarta: Rajawali, 1990.

Syaiful Bahri,Psikologi Pendidikan Hasil Belajar. Jakarta: PT Rineka Cipta. Indra. 2009

Syamsuddin, Abin, Pedoman Studi Psikologi Kepribadian. Bandung : IKIP Bandung, 1990. 